\title{
PEMILIHAN DAN PEMBENTUKAN KATA DALAM BERITA MEDIA CETAK DI KALIMANTAN SELATAN
}

\author{
Musdalipah \\ Balai Bahasa Kalimantan Selatan \\ Jalan Jenderal Ahmad Yani, Km. 32, Loktabat, Banjarbaru \\ Posel.mussasi_ok@yahoo.co.id
}

\begin{abstract}
Abstrak
Jurnalis memiliki kemampuan memengaruhi masyarakat melalui bahasa yang mereka gunakan dalam menyampaikan informasi. Masalahnya, tidak semua jurnalis memiliki kemahiran dalam hal penggunaan bahasa. Untuk itulah perlu diadakan penelitian mengenai pemilihan dan pembentukan kata di media massa cetak, terutama yang terbit di Kalimantan Selatan. Kajian ini diharapkan menjadi acuan para jurnalis untuk perbaikan kesalahan penggunaan bahasa di media massa. Pendekatan deskriptif kualitatif digunakan untuk mendeskripsikan data yang dianalisis. Sampel data berjumlah 29 berita dari lima media massa cetak: Radar Banjar, Banjarmasin Post, Kalimantan Post, Mata Banua, dan Barito Post yang terbit di Kalimantan Selatan pada Maret 2019. Hasi penelitian menunjukkan, kesalahan pemilihan dan pembentukan kata meliputi penggunaan kata hubung intrakalimat dan antarkalimat, kata depan, unsur serapan, kata tidak baku, dan kata bentukan setelah mendapat imbuhan.
\end{abstract}

Kata kunci: Kesalahan Diksi, Bahasa Koran

Word Choice and Formation in News Articles in Printed Mass Media in South Kalimantan

Abstract

Journalists have a strong ability to influence society through the language which they use in conveying information. However, some of the journalists do not have proficiency in standard language. Hence, there is a need to study the word choice and formation in printed mass media, published particularly in South Kalimantan. The study is intended for the journalists to use as a reference to improve their proficiency in using language in mass media. Qualitative descriptive analysis is used to describe the data. The data sample consists of 29 news articles from five printed mass media: Radar Banjar, Banjarmasin Post, Kalimantan Post, Mata Banua, and Barito Post. The selected article was published in March 2019. The result showed word choice and word formation errors consist of errors in using conjunctions that link words in a sentence and between sentences, prepositions, loan words, substandard words, and derivatives.

Keywords: word choice error, Newspaper Language

\section{PENDAHULUAN}

Masalah kebahasaan dapat menjadi topik yang menarik untuk dibahas sebab sifatnya yang dinamis. Demikian pula pembahasan mengenai kebahasaan di Indonesia sebab jumlah bahasa dan latar belakang penuturnya sangat beragam. Jumlah bahasa daerah di Indonesia serta bahasa asing yang masuk ke Indonesia turut memengaruhi penggunaan bahasa, baik ragam formal maupun nonformal ataupun ragam lisan maupun ragam tulis. Selain itu, teknologi dan globalisasi turut pula memengaruhi penggunaan bahasa di Indonesia.

Pengguna bahasa yang dapat memengaruhi masyarakat, di antaranya, ialah para jurnalis yang menjadikan media massa sebagai alat penyampaian informasi, termasuk informasi kebahasaan. Media massa dapat menjadi wadah yang efektif untuk memberikan contoh atau praktik penggunaan bahasa yang baik. Masyarakat memiliki kecenderungan mengikuti bahasa yang digunakan oleh media massa.

Masalahnya, tidak semua jurnalis di media massa memiliki kemahiran dalam hal penggunaan bahasa, baik lisan maupun tulisan. Untuk itulah perlu diadakan penelitian mengenai pemilihan dan pembentukan kata di media massa cetak, terutama yang ada di wilayah Kalimantan Selatan.

Beberapa kajian sejenis sebelumnya pernah dilakukan, di antaranya 
oleh Khairun Nisa (2018) yang dimuat dalam Jurnal Bindo Sastra Volume 2, Nomor 2, Tahun 2018 terbitan Universitas Muhammadiyah Palembang dengan judul "Analisis Kesalahan Berbahasa pada Berita dalam Media Surat Kabar Sinar Indonesia Baru". Kajian tersebut berfokus dengan data dari berita koran Sinar Indonesia Baru edisi Desember 2017 dan menghasilkan simpulan bahwa terdapat bentuk kesalahan berbahasa di bagian ejaan, morfologi, sintaksis, dan semantik.

Selain penelitian Nisa tersebut, ada penelitian Alfiyani dkk yang mengkaji kesalahan berbahasa pada surat kabar jawa Pos dan Radar Solo edisi Januari--Maret 2020(Alfiyani, 2020). Berdasarkan hasil penelitian ditemukan kesalahan berbahasa tataran ejaan pada bentuk kesalahan penulisan kata, kesalahan huruf kapital, kesalahan tanda koma, kesalahan penulisan bilangan, kesalahan penggunaaan tanda titik dan titik dua, dan kesalahan penggunaan partikel. Kesalahan pada tataran sintaksis yang berwujud tataran morfologi berwujud kesalahan sufiks, kesalahan perfiks, dan kesalahan reduplikasi. Kesalahan pada tataran wacana dengan wujud kesalahan penggunaan acuan dan kesalahan terdapat beberapa topik dalam satu paragraf (hlm.33).

Kesalahan berbahasa tidak hanya ditemukan pada surat kabar, di dalam artikel jurnal ilmiah dan tulisan narasi guru-guru pun juga banyak ditemukan kesalahan berbahasa. Penelitian Darmawati yang mengakaji kemampuan menulis guru di Kabupaten Boalemo, Gorontalo juga menemukan beberapa kesalahan pemilihan kata dalamtulisan naratif guru ((NFN, Darmawati, 2018) mengungkap hal tersebut. Selain itu, penelitian Dinanti juga menemukan kesalahan penggunaan bahasa Indonesia dalam Jurnal Ilmiah Pendidikan
MIPA, $\quad$ FKIP Universitas Bengkulu.((Dinanti, 2019).

Berbeda dengan kajian Khairun Nisa dan Alfiyani dkk. tersebut, kajian ini berfokus dengan tujuan mendeskripsikan kesalahan pemilihan dan pembentukan kata dalam berita di media massa cetak di Kalimantan Selatan dan memberikan saran perbaikannya.

Hasil kajian ini diharapkan menjadi acuan para jurnalis, juga pemerhati bahasa lainnya untuk perbaikan kesalahan penggunaan bahasa di media massa cetak, khususnya di Kalimantan Selatan.

Bahasa pada media massa sejatinya merupakan bahasa lisan yang ditulis sehingga masuk ke dalam ragam nonformal dan popular. Hal ini seiring dengan pendapat Riceur dalam Sobur (2001)yang menyatakan bahwa teks adalah wacana (berarti lisan) yang diklasifikasikan dalam bentuk tulisan. Dengan demikian, jelas bahwa teks merupakan fiksasi atau pelembagaan sebuah peristiwa wacana lisan dalam bentuk tulisan (hlm. 53).

Seiring dengan laju perkembangan dunia yang global, bahasa Indonesia ragam baku juga sebaiknya digunakan di media massa, terutama media massa cetak. Hal ini diperlukan untuk memperkenalkan kaidah dan kosakata baku bahasa Indonesia ke masyarakat sehingga kesalahan berbahasa di masyarakat dapat dihindari.

\section{Diksi dan Pembentukan Kata}

Diksi atau pemillihan kata menurut Sasangka (2018) adalah pemakaian kata yang tepat dan selaras untuk mengungkapkan suatu gagasan. Pilihan kata bisaanya digunakan untuk membedakan nuansa makna secara jitu sehingga kata yang dipilih benar-benar dapat mengungkapkan gagasan secara tepat (hlm.97). 
Pemilihan kata yang tepat menurut Sasangka (2018) akan membantu seseorang dalam mengungkapkan apa yang ingin disampaikannya kepada orang lain secara tepat pula, baik secara lisan maupun secara tulis. Di samping itu, pemilihan kata harus pula dilakukan sesuai dengan situasi dan penggunaan kata itu (hlm. 97).

Ketika memilih kata, Sasangka (2018)mengatakan bahwa ada beberapa hal yang perlu diperhatikan, yaitu kata apa yang tepat untuk digunakan pada saat berbahasa dan kata yang dipilih harus tepat, benar, lazim, dan layak (hlm. 99).

Ketepatan adalah kemampuan sebuah kata untuk menimbulkan gagasan yang sama pada imajinasi pembaca atau pendengar, seperti yang dipikirkan atau dirasakan oleh penulis atau pembicara. Setiap penulis atau pembicara harus berusaha secermat mungkin memilih kata-kata untuk mencapai maksud tertentu. Kata yang dipakai oleh penulis atau pembicara dikatakan sudah tepat apabila ada reaksi selanjutnya, baik berupa aksi verbal maupun nonverbal dari pembaca atau pendengar. Selain itu, ketepatan juga tidak akan menimbulkan kesalahpahaman antara kedua pihak yang sedang berkomunikasi. Secara umum, menuurt Keraf (2002) persyaratan pilihan kata, meliputi (1) ketepatan, kelaziman, dan (3) kecermatan (hlm. 88). Hakikatnya, menurut Sasangka (2018), kata dibedakan atas dua segi, yaitu bentuk dan makna. Bentuk merupakan wujud yang dapat didengar atau dibaca, sedangkan makna merupakan reaksi pikiran yang muncul karena adanya bentuk itu.Berdasarkan bentuknya, kata dibedakan menjadi tiga, yakni (1) kata asal, (2) kata dasar, dan (3) kata jadian atau kata turunan (hlm. 57).
Pembentukan kata meurut Sasangka (2018) meliputi (1) bentuk kata, (2) pengimbuhan atau afiks, perulangan, (4) pemajemukan, pengurangan, dan (6) kata baku dan tidak baku (hlm.57—96).

\section{METODE PENELITIAN}

Penelitian ini menggunakan pendekatan deskriptif kualitatif untuk mendeskripsikan data yang dianalisis, yakni kesalahan pemilihan diksi dan pembentukan kata dalam berita di media massa cetak di Kalimantan Selatan. Tahapan yang digunakan dalam penelitian ini adalah pengumpulan data, pengananalisisan data, dan penyajian hasil data Sudaryanto (1993).

Data penelitian ini berupa berita di media massa cetak yang terbit di Kalimantan Selatan pada Maret 2019 berjumlah 29 berita. Data-data tersebut bersumber dari lima media massacetak, yakni Radar Banjarmasin Edisi Maret(2019), Banjarmasin Post Edisi Maret(2019), Kalimantan Post Edisi Maret(2019), Mata Banua Edisi Maret(2019), dan Barito Post Edisi Maret(2019).

Teknik penelitian ini mengikuti pendapat Sudaryanto (1993), yakni menggunakan teknik baca dan catat untuk mengungkap permasalahan yang terdapat di dalam suatu bacaan (hlm. 43). Data dibaca, dicatat, diklasifikasi,diberi kode untuk mempermudah analisis, dan selanjutnya ditulis dalam bentuk kalimat dan paragraf.

\section{HASIL DAN PEMBAHASAN SKH Radar Banjarmasin (1) Data RB1}

Data RB1 memuat ketidaktepatan dalam penulisan bentuk terikat pasca- yang ditulis 
terpisah dengan kata setelahnya, yaitu pasca kejadian. Penulisan yang tepat ialah pascsakejadian. Ketidaktepatan pemilihan diksi juga terdapat pada awal kalimat, yakni [Sedangkan bahan galiannya setelah dipilah dapat dikirim ke lokasi-lokasi tambang yang akan direklamasi.]. Kata sedangkan merupakan kata penghubung dalam kalimat majemuk setara yang didahului tanda baca koma [,]. Kata hubung antarkalimat dalam kalimat tersebut sebaiknya diganti menjadi [Selanjutnya, bahan galian yang telah dipilah dapat dikirim ke lokasi-lokasi tambang yang akan direklamasi.].

\section{(2) Data RB2}

Data RB2 memuat gabungan katayang diperlukan dalam kalimat berikut [Bukannya bersatu untuk bersama-sama memikirkan masyarakat, dua wakil rakyat di Kota Idaman: Wakil Ketua DPRD Banjarbaru Neny Hendriyatiwaty dan Wakil Ketua Komisi II A Murjadi justru berselisih.]. Frasa yang dianggap mubazir, untuk bersama-sama, dapat dihilangkan sehingga kalimatnya menjadi [Bukannya bersatu memikirkan masyarakat, dua wakil rakyat di Kota Idaman, Wakil Ketua DPRD Banjarbaru, Neny Hendriyatiwaty, dan Wakil Ketua Komisi II, A Murjadi, justru berselisih.].

\section{(3) Data RB3}

Data RB3 memuat kesalahan pembentukan kata. Kesalahan ini terdapat dalam penulisan imbuhan $d i$ - yang dipisah [... tanpa itu tongkang bisa saja hanyut di bawa gelombang.]. Kesalahan ini dapat diperbaiki menjadi [...tanpa itu tongkang bisa saja hanyut dibawa gelombang.].

\section{(4) Data RB4}

Data RB4 memuat ketidaktepatan pemilihan kata. Hal ini tampak dalam kalimat [Karena, mengalami luka bakar pada kedua belah telapak tangannya. Serta bagian dada kanan, dada kiri dan leher belakang.]. Pemilihan kata hubung intrakalimat karena dan serta di awal kalimat tidak tepat. Kedua kata tersebut seharusnya berada di dalam kalimat, bukan di awal kalimat seperti data tersebut.Diksi dada kanan dan dada kiri dapat diefektifkan menjadi dada saja sebab satu kata ini sudah cukup untuk menginformasikan dada kiri dan dada kanan.

\section{(5) Data RB5}

Data RB5 memuat ketidaktepatan pemilihan diksi dalam dua kalimat berikut. [Saat jam landing pesawat Sandi memang kata Adit termasuk jadwal yang cukup padat.]dan [Sebelumnya, kedatangan Capres Nomor urut 02, Sandiaga Uno ke acara Haul Guru Sekumpul ke-14 pada Mingggu (10/03) malam sempat diisukan tertahan karena pesawat private yang membawanya tidak diizinkan mendarat.]. Diksi saat jam, landing, dan private tersebut dapat diganti dengan waktu, pendaratan, dan pribadi, sebab kedua kata berbahasa asing tersebut memiliki padanan dalam bahasa Indonesia. Sementara itu, kata memang dapat dihilangkan sebab tanpa kata tersebut informasi yang ingin disampaikan sudah dapat diterima pembaca.

\section{(6) Data RB6}

Data RB6 memuat kesalahan dalam penulisan kata depan ke yang dirangkai dengan kata sesudahnya. Kesalahan tersebut ada dalam kalimat [Azhar berharap, dalam tiga hari kedepan, investigasi itu sudah rampung.]. Kata depan ke tersebut seharusnya dipisah menjadi [Azhar berharap, dalam tiga hari ke depan, investigasi itu sudah rampung.].

Ketidaktepatan pemilihan diksi lainnya terdapat dalam kalimat [Melainkan sudahkah penertiban APK itu memenuhi prosedur atau belum]. Diksi sudahkah dan memenuhi dapat diganti agar memperjelas makna. Kedua diksi tersebut dapat diganti 
menjadi apakah dansesuai, sedangkan atau belum sebaiknya dihilangkan sehingga menjadi [... melainkan apakah penertiban APK itu sesuai prosedur?].

\section{(7) Data RB7}

Data RB7 memuat kesalahan pemilihan kata hubung intrakalimat tapi yang digunakan di awal kalimat berikut ini. [Tapi, tidak disebutkan jabatan apa yang diincar oleh pejabat asal Kotabaru itu.]. Kata hubung antarkalimat yang tepat dalam kalimat tersebut adalah namun, sedangkan tetapi atau tapi merupakan kata hubung dalam kalimat majemuk.

\section{(8) Data RB8}

Data RB8 memuat ketidaktepatan pemilihan kata jika, mendownload, minta ampun, terpaksa, dan menggilir. Katakatatersebut ada dalam kalimat [Jika semua komputer mendownload soal audio, leletnya minta ampun. Terpaksa, guru menggilir anak-anak menjawab.]. Diksi jika dapat diganti menjadi ketika. Penulisan mendownload harus menggunakan tanda baca hubung [-] antara imbuhan men- dan download. Penulisan kata download harus cetak miring atau sebaiknya diganti dengan padanan dalam bahasa Indonesia, yaitu mengunduh. Minta ampunseharusnya diganti dengan sangat. Kata terpaksa dapat diletakkan setelah anak-anak. Kata menggilir dapat diganti dengan bergiliran untuk menimbulkan rasa yang lebih berterima meski tidak mengubah makna. Dengan demikian, akan menjadi menjadi [Ketika semua komputer mengunduh soal audio, jaringannya sangat lelet. Anak-anak terpaksa menjawab secara bergiliran.] atau[ Ketika semua komputer men-download soal audio, jaringannya sangat lelet. Anak-anak terpaksa menjawab secara bergiliran.

\section{SKH Banjarmasin Post}

(9) Data BPost1
Data BPost1 memuat kesalahan pemilihan kata seperti berikut ini. [Sedangkan untuk armada truk, trailer, fuso mulai $\mathrm{H}$ minus satu sampai $\mathrm{H}$ plus tiga dilarang beroperasional alias libur melewati Jalan A Yani Martapura.]. Kata sedangkan merupakan kata hubung intrakalimat sehingga penggunaannya bukan di awal kalimat. Diksi tersebut dapat diganti dengan sementara itu atau namun dan diikuti tanda baca koma [,] yang merupakan kata hubung antarkalimat.Kata fuso harus didahului kata hubung dandalam pemerincian tersebut.Jika pemerincian setara lebih dari dua, perlu digunakan kata hubung dan sebelum perincian yang terakhir. Diksi beroperasional dalam kalimat tersebut tidak tepat sebab kata tersebut bermakna 'secara (bersifat) operasi', sedangkan yang dimaksud ialah aktivitasnya. Diksi yang tepat dalam kalimat ini ialah beroperasi. Diksi alias dalam kalimat tersebut juga tidak tepat sebab mengacu kepada namalain seseorang, bukan pada istilah atau aktivitas. Diksi yang tepat mengganti kata tersebut ialah atau. Penulisan nama jalan $A$ Yani seharusnya tidak disingkat, kecuali lebih dari dua kata. Diksi yang tepat mengganti singkatan tersebut ialah Ahmad Yani.

Ketidaktepatan diksi juga terdapat dalam kalimat berikut, [Demi kelancaran pelaksanaan haul dan jamaah yang hadir bisa pulang dengan tertib, Satuan Lantas Polres Banjar memberikan himbauanhimbauan.]. Kata himbauan dan jamaah merupakan kata yang tidak baku dan dalam kalimat ini dapat diganti menjadi kata baku, yakni imbauan dan jemaah.

Ketidaktepatan diksi lainnya terdapat dalam kalimat [Agar datang dan pulang ke daerah asalnya bisa tertib.]. Diksi bisa tersebut dapat diganti menjadi secara.

\section{(10) Data BPost2}


Data BPost2 memuat diksi yang tidak tepat terdapat seperti berikut [Proyek pengembangan Bandara Syamsuddin Noor Banjarmasin di Banjarbaru dikebut siang dan malam proyek dikerjakan.]. Penggunaan diksi [proyek dikerjakan] tidak efektif dan dapat dipindah ke awal kalimat sebagai berikut.[Pengerjaan proyek pengembangan Bandara Syamsuddin Noor Banjarmasin di Banjarbaru dikebut siang dan malam.].

Diksi yang tidak tepat terdapat dalam kalimat [Pimpinan Project (Pimpro) Proyek Pengembangan Bandara Syamsuddin Noor (PPDJ), ...]. Diksi Project tersebut tidak tepat sebab diksi proyek sudah digunakan setelahnya sehingga menjadi mubazir. Demikian pula diksi pimpro tidak diperlukan lagi dalam kalimat tersebut, sehingga dapat diperbaiki menjadi [Pimpinan Proyek Pengembangan Bandara Syamsuddin Noor (PPDJ), ...].

\section{(11) Data BPost3}

Data BPost3 ini memuat kesalahan diksi dalam kalimat [Dalam bincang santai dipandu Miranda Seftiani yang dikemas talk show tersebut, Heri lebih banyak bicara tentang perjalanan karir dan aktifitas literasinya. Sekaligus mempromosikan rencana novel Balada Si Roy yang bakal di film kan setelah 30 tahun noveltersebut dirilis.]. Penggunaan istilah asing talk show dalam kalimat tersebut tidak tepatsebab sudah ada padanannya dalam bahasa Indonesia, yakni gelar wicara. Istilah asing tersebut dapat digunakan, tetapi harus ditulis dengan huruf miring. Selain itu, kata karir dan aktifitas merupakan bentuk tidak baku dari karier dan aktivitas, sehingga sebaiknya diganti menjadi bentuk baku.

Kesalahanpembentukan kata terdapat pada penulisan di film kan dan difilm-kan dalam kalimat [... rencananya difilm-kan oleh Mathias Muchus dan kawan-kawan.].
Penulisan imbuhan harus dirangkai dengan kata dasar atau bentuk dasarnya tanpa tanda hubung [-], sehingga seharusnya diganti menjadi difilmkan.

\section{(12) Data BPost4}

Data BPost4 memuat kesalahan diksi dalam kalimat [Tapi seperti diketahui Hermansyah kini dilantik Gubernur Jabar Ridwan Kamil, maka jabatan tersebut kosong lagi.]. Kata tapi merupakan kata hubung intrakalimat, sedangkan kata hubung antarkalimat ialah namun dan jadi. Kalimat tersebut tidak memerlukan kata hubung antarkalimat agar tidak membuat pembaca sulit memahaminya. Kata lagi dapat diganti menjadi kembali.Dengan demikian, perbaikannya dapat seperti berikut.[Seperti diketahui, Hermansyah kini dilantik Gubernur Jabar, Ridwan Kamil, menjadi pejabat di Jabar sehingga jabatan Kadis Perkim kembali kosong.].

\section{(13) Data BPost5}

Data BPost5 memuat kesalahan diksi, yakni penggunaan kata hubung intrakalimat di awal kalimat berikut. [Melainkan mulai dan ajaklah mereka melakukan gerakangerakan.]. Kata hubung melainkan dalam kalimat tersebut dapat diganti menjadi namun. Dengan demikian, perbaikan menjadi [Namun, mulai dan ajaklah mereka melakukan gerakan-gerakan.].

\section{(14) Data BPost6}

Data BPost6 memuat kesalahan dalam pembentukan kata [insya Allah]. Penulisan kata ini seharusnya dirangkai menjadi satu kata, sebagaimana kata alhamdulillah dan subhanallah yang ada padanannya dalam bahasa Indonesia. Meskipun kata ini berasal dari bahasa Arab, penulisannya mengikuti kaidah bahasa Indonesia sebab sudah diserap ke dalam bahasa Indonesia. Penulisan yang sesuai kaidah bahasa Indonesia menjadi [insyaallah]. 


\section{SKH Kalimantan Post}

\section{(15) Data KP1}

Data KP1 memuat kesalahan penulisan kata depan ke yang dirangkai dengan kata yang mengikutinya seperti dalam judul berita berikut ini. [Guru SMAN 1 Paringin Lulus Pendidikan Keluar Negeri]. Penulisan Keluar dalam judul tersebut tidak tepat sebab berdasarkan kaidah bahasa Indonesia penulisan kata depan harus dipisah dengan kata sesudahnya. Dengan demikian, perbaikan menjadi [Guru SMAN 1 Paringin Lulus Pendidikan ke Luar Negeri].

Kesalahan diksi lainnya terdapat dalam kalimat berikut ini. [Dirinya sendiri, menurut Dharma, bersama 30 guru lainnya termasuk rombongan P4TK, Guru PKN dan IPS akan diberangkatkan ke Australia, dimana nantinya akan berada di negeri kanguru tersebut antara tiga sampai lima pekan guna menjalankan program bagi guru berprestasi ini.]. Kata sendiri dan akan termasuk mubazir sehingga dapat dihilangkan. Sementara itu, kalimat ini dibagi menjadi dua, kata dimana diganti menjadi mereka dan menjadi awal kalimat kedua. Kata guna dapat diganti menjadi untuk.

\section{(16) Data KP2}

Data KP2 memuat ketidaktepatan diksi dalam kalimat berikut, [... kreativitas dan inovasi yang ditampilkan dan disuguhkan dalam event tersebut melalui stand selalu ada yang baru,]. Kata event dan stand tersebut merupakan bahasa asing yang yang sudah diserap ke dalam bahasa Indonesia, sehingga seharusnya diganti menjadi stan dan acara atau kegiatan.

\section{(17) Data KP3}

Data KP3 memuat kesalahan pembentukan kata, yakni mensejahterakan dalam kalimat [', $\quad$ mampu mensejahterakan masyarakat kita," katanya]. Sesuai kaidah bahasa Indonesia yang berlaku, kata dasar berawalan huruf $[\mathrm{k} / \mathrm{p} / \mathrm{t} / \mathrm{s}]$ akan luluh ketika dilekati prefiks men-, meng-, atau meny-, sehingga kata tersebut seharusnya diganti menjadi menyejahterakan.

Kesalahan lainnya adalah penulisan prefiks yang tidak melekat dengan kata sesudahnya, yakni di terapkan dalam kalimat[... program serasi yang di terapkan oleh pemerintah pusat.]. Sufiks harus ditulis serangkai dengan kata dasar atau bentuk dasarnya, sehingga kata tersebut seharusnya menjadi diterapkan.

Kesalahan lainnya adalah kata perhektar yang seharusnya dipisah antara per denagn hektare, sebab merupakan dua kata dan kata per bermakna 'setiap'. Diksi hektar pun tidak tepat sebab yang sesuai kaidah bahasa Indonesia ialah hectare, sehingga seharusnya menjadi perhektare.

Kesalahan lain terdapat pada penulisan gabungan kata membudi dayakandalam kalimat [... bertani sambil membudi dayakan ikan.]. Gabungan kata ini seharusnya ditulis serangkai sebab telah mendapatkan prefiks dan sufiks atau awalan dan akhiran secara bersamaan, sehingga seharusnya menjadi membudidayakan.

Kesalahan diksi juga terdapat dalam kalimat berikut, [Karena itu lanjut dia ...]. Kata hubung karena ditulis di awal kalimat tersebut. Karena adalah kata hubung intrakalimat yang berfungsi sebagai penghubung antara induk dan anak kalimat. Kata tersebut dapat diganti dengan kata hubung antarkalimat, seperti [Oleh karena itu, lanjut dia, ...].

Kesalahan lainnya ada dalam penulisan nama kota terdiri atas kata ulang yang ditulis menggunakan tanda hubung [], yakni Bati-Bati yang seharusnya ditulis menjadi satu kata tanpa tanda hubung. Hal ini mengacu pada Permendagri No. 39 
Tahun 2008 tentang Pedoman Umum Pembakuan Nama Rupabumi, sehingga penulisan yang benar menjadi Batibati.

\section{(18) Data KP4}

Data KP4 memuat kesalahan penulisan kata berimbuhan yang ditulis terpisah antara awalan dengan kata dasarnya, yakni di lantik. Penulisan awalan seharusnya dirangkai dengan kata yang dilekatinya.

Kesalahan lainnya adalah penggunaan kata hubung intrakalimat bahkan yang ditulis di awal kalimat [Bahkan juga harus mampu menyelenggarakan pemerintahan yang baik, ...]. Kata tersebut sebaiknya diganti dengan kata hubung antarkalimat selain itudan kalimatnya diperbaiki menjadi [Selain itu, bupati juga harus mampu menyelenggarakan pemerintahan yang baik, ...].

\section{(19) Data KP5}

Data KP5 memuat diksi taqwa dalam kalimat [... mukmin yang bertaqwa ...]. Diski ini berasal dari bahasa Arab yang diserap dan disesuaikan penulisannya ke dalam bahasa Indonesia, yakni takwa.

\section{SKH Mata Banua}

\section{(20) Data MB1}

Data MB1 memuat kesalahan penggunaan kata hubung antarkalimat namun di dalam kalimat [BKPRMI HST sengaja mendatangkan narasumber dari Banjarmasin yaitu Ustadz Rahmat Hidayat, namun beliau merupakan trainer Al Qur'an Nasional.]. Kata hubung tersebut tidak diperlukan sebab bukan kalimat majemuk yang bertentangan. Frasa beliau merupakan trainer dapat diganti seorang pengajar dan ustadz diganti sesuai kaidah bahasa Indonesia, yakni ustaz. Dengan demikian, kalimat tersebut menjadi [BKPRMI HST sengaja mendatangkan narasumber dari
Banjarmasin, Ustaz Rahmat Hidayat, seorang pengajar Al Qur'an tingkat nasional.].

Diksi yang berlebihan terdapat dalam kalimat [Adapun tujuan kegiatan ini adalah untuk meningkatkan ...]. Kata untuk tidak diperlukan lagi jika sebelumnya telah digunakan kata tujuan sebab kedua kata tersebut bermakna sama, sehingga harus dipilih salah satu saja dalam kalimat seperti itu. Dengan demikian, kalimatnya menjadi [Tujuan kegiatan ini adalah meningkatkan ...] atau [Kegiatan ini bertujuan meningkatkan ...].

Ketidaktepatan lainnya terdapat dalam kalimat berikut [Menurut ketua Majelis Pertimbangan Daerah (MPD) BKPRMI HST yang juga panitia pelaksana dalam kegiatan ini $\mathrm{H}$ Zainur Rahmani mengatakan bahwa selama satu hari sejak pagi pukul 09.00 sampai selesai dan dikhususkan bagi ustadz dan ustadzah para pengajar TK dan TPA sekabupaten HST.]. Kata menurut di awal kalimat tersebut tidak diperlukan sebab sudah ada kata mengatakan yang bermakna sama. Selain itu, diksi ustadz dan ustadzah dapat diganti menjadi ustaz dan ustazah.

\section{(21) Data MB2}

Data MB2 memuat ketidaktepatan diksi dalam kalimat [... berdasarkan prinsip-prinsip kemitraan dengan LSM, Komunitas dan juga Pemerintah Daerah," ...]. Diksi juga tidak diperlukan dalam kalimat tersebut sebab sudah menggunakan kata hubung dan, sehingga menjadi [... berdasarkan prinsip-prinsip kemitraan dengan LSM, komunitas, dan pemerintah daerah,"...].

Kesalahan pembentukan kata terdapat dalam kata mensukseskan dan mempengaruhi. Sesuai kaidah bahasa Indonesia yang berlaku, kata dasar berawalan huruf $[\mathrm{k} / \mathrm{p} / \mathrm{t} / \mathrm{s}]$ akan luluh ketika 
dilekati awalan atau prefiks men-, mem-, meng-, atau meny-, sehingga seharusnya menyukseskan dan memengaruhi.

\section{(22) Data MB3}

Data MB3 memuat kesalahan diksidan pembentukan katadalam judul berita, yaitu [Motoris Klotok Sepakat dengan Wali Kota]. Diksi klotok tidak tepat sebab seharusnya kelotok. Kata merubah dan dirubah dalam kalimat [.., kesepakatan merubah kelotok pun karena dijanjikan akan mendapat bantuan ...] dan [... yang dirubah desain seperti anjuran Dishub ...]. Pembentukan kata yang benar sesuai kaidah bahasa Indonesia untuk kata ini ialah mengubah dan diubah, sebab kata dasarnya $u b a h$, bukanrubah.

\section{(23) Data MB4}

Data MB4 memuat kesalahan penulisan frasa bekerjasama yang dirangkai. Frasa yang hanya dilekati prefiks atau sufiks, dua kata dasarnya tidak perlu dirangkai, kecuali jika dilekati konfiks, sehingga seharusnya bekerja sama.

\section{(24) Data MB5}

Data MB5 kesalahan diksidalam judul berita [PUPR Review Ulang] dan kalimat [... (PUPR) Kota Banjarmasin mereview ulang berkas ...]. Penggunaan kata Reviewdan mereviewkurang tepat sebab kata tersebut ada padanannya dalam bahasa Indonesia, yakni kaji dan mengkaji.

\section{SKH Barito Post}

\section{(25) Data BP1}

Data BP1 memuat diksi yang tidak baku, yakni menghimbau dalam kalimat [... pihak Pemerintah Provinsi selalu menghimbau kepada masyarakat, ..]. kata himbau merupakan bentuk tidak baku dari kata imbau, sehingga sebaiknya diganti dengan mengimbau. Demikian pula diksi shalat yang berasal dari bahasa Arab yang diserap dan ditulis sesuai kaidah bahasa Indonesia, yakni salat.
Ketidaktepatan diksi lainnya terdapat dalam judul berita [KPU Sortir dan Pelipatan Surat Suara, Pemkab Terus Menfasilitasi]. Diksi Pelipatantersebut tidak sejajar dengan kata Sortir yang menggunakan kata hubung dan di antara keduanya. Demikian pula dengan diksi Menfasilitasi tidak tepat, sehingga judul tersebut dapat diperbaiki menjadi [KPU Sortir dan Lipat Surat Suara, Pemkab Terus Fasilitasi].

Ketidaktepatan diksiterdapat dalam kalimat [Dia mengingat ajang pemilu 2019 ini, para ASN bersifat netral.]. Diksi mengingat dan bersifat dalam kalimat tersebut tidak tepat sebab keberadaannya membuat pembaca kesulitan memahami isi teks kalimat, sehingga dapat diganti menjadi mengingatkan dan bersikap. Demikian pula sebelum kata ajang perlu ditambah kata dalam dan kata para dihilangkan sebab $A S N$ sudah bermakna jamak, sehingga kalimatnya menjadi [Dia mengingatkan, dalam ajang pemilu 2019 ini, ASN bersikap netral.].

Kesalahan lainnya adalahpensortiran yang sesuai kaidah bahasa Indonesia penyortiran. Demikian pula penulisan kata insya Allah yang tidak sesuai kaidah bahasa Indonesia. Kata ini seharusnya ditulis mengikuti kaidah bahasa Indonesia, yakni insyaallah. Selain itu terdapat pula kesalahan dalam penulisan kata depan yang dirangkai dengan kata sesudahnya, yakni kedepan. Penulisan preposisi atau kata depan seharusnya dipisah dengan kata sesudahnya, ke depan. Kesalahan penulisan bentuk terikat non-terdapat dalam [... BPD non proses.], seharusnya [... BPD nonproses]. Kesalahan lainnya terdapat dalam [“... termasuk mempacking surat suara," ucapnya.].Diksi mempacking tersebut tidak tepat sebab bahasa asing yang memiliki padanan dalam bahasa Indonesia, 
sehingga sebaiknya diganti dengan diksi bahasa Indonesia, yakni mengepak.

\section{(26) Data BP2}

Data BP2 memuat ketidaktepatan pembentukan kata mensosialisasikan dalam kalimat berikut [Yamin berharap kepada dinas terkait, dalam hal ini dinas kebersihan harus lebih mensosialisasikan aturan persampahan, ...]. Kata dasar berawalan huruf $[\mathrm{k} / \mathrm{p} / \mathrm{t} / \mathrm{s}]$ huruf awalnya luluh ketika dilekati prefiks men-, meng-, atau meny-, sehingga kata dasar sosialisasi ketika dilekati imbuhan meny- dan -kan menjadi menyosialisasi.

Kesalahan lainnya ada dalam kalimat [..., padahal sudah jelas di atur dalam Perda bahwa pembuangan sampah pada malam hari.]. Penulisan prefiksdi- seharusnya serangkai dengan kata dasar atur, sehingga menjadi diatur. Sebaliknya, dalam judul berita [Oknum ASN Diduga Buang Sampah Diluar Jam Ditentukan] memuat kesalahan penulisan diduga sebab kata depan $d i$ seharusnya dipisah dengan kata sesudahnya. Selain itu, setelah kata jam sebaiknya disisipi kata yang sebagai keterangan.

Kesalahan diksi lainnya terdapat
dalam penggunaan kata hubung
antarkalimat namun yang digunakan sebagai penghubung intrakalimat berikut [..., namun bagi salah satu oknum ASN yang satu ini tidak perlu dicontoh, ...]. Diksi tersebut sebaiknya diganti dengan diksi tetapi.

Kesalahan diksi lainnya terdapat dalam pemilihan kata hubung intrakalimat yang digunakan di awal kalimat berikut, [Karena sesuai aturan perda, bagi yang melanggar ...]. Diksi karena dapat dihilangkan sebab tidak mengubah maksud dari kalimat tersebut. Selain itu, kata aturan juga dapat dihilangkan sebab bermakna sama dengan kata perda atau peraturan daerah, sehingga kalimatnya dapat diganti menjadi [Sesuai perda, bagi yang melanggar ...].

\section{(27) Data BP3}

Data BP3 memuat ketidaktepatan diksidalam judul berita [Bangun Septic Tank Sesuai Kreatifitas Warga]. Kata kreatifitas bukan bentuk baku sehingga sebaiknya diganti menjadi bentuk baku, yakni kreativitas.

Kesalahan diksi lainnya terdapat dalam kalimat berikut ini. [“...bentuknya dikreasikan dan berinovasi sesuai dengan kreatifitas warga," katanya.]. Penggunaan kata berinovasi tidak tepat sebab tidak sejajar dengan kata kerja sebelumnya dikreasikan, yaitu kata kerja pasif dan kata kerja aktif. Kata hubung kedua kata tersebut menggunakan kata hubung dan, sehingga kata yang dihubungkannya pun harus setara. Dengan demikian, kata kerja aktif berinovasi dapat dipasifkan menjadi diinovasikan, sehingga perbaikan kalimat tersebut menjadi [“....bentuknya dikreasikan dan diinovasikan sesuai dengan kreativitas warga," katanya.].

\section{(28) Data BP4}

Data BP4 memuat kesalahan diksi dalam kalimat berikut. [... tausyiahnya mengingatkan agar kita jangan lupa sholat berjamaah, hadir pada majelis-majelis ta'lim, ...].Kata tausyiah, sholat, dan ta'limbukan bentuk baku sehingga seharusnya diganti menjadi tausiah, salat, dan taklim. Demikian pula diksi beristiqfar dalam kalimat [... diminta untuk beristiqfar ...] diganti menjadi beristigfar.

\section{(29) Data BP5}

Data BP5 memuat ketidaktepatan diksishalat, fardhu, taqwa, adzan, SWT, dan Isra' Mi'raj. Kata-kata tersebut berasal dari bahasa Arab yang telah diserap ke dalam bahasa Indonesia. Penyerapan ini mengubah bentuk yang telah disesuaikan dengan 
kaidah bahasa Indonesia menjadi salat, fardu, takwa, azan, Swt., dan Isra Mikraj.

Kesalahan pembentukan kata bekerjasama. Gabungan kata yang hanya mendapat awalan, menurut kaidah bahasa Indonesia, tidak ditulis serangkai, kecuali jika awalan dan akhiran melekatinya secara bersamaan. Dengan demikian, pembentukan gabungan kata tersebut seharusnya bekerja sama.

Diksi penceramah dalam kalimat [Penceramah dalam peringatan Isra Mi'raj ini disampaikan oleh Prof DR H Mujiburrahman,] tersebut tidak tepat sebab secara semantik tidak berterima dengan kata kerjanya. Diksi penceramah tersebut dapat diganti menjadi ceramah.

\section{PENUTUP}

Dari hasil analisis data tersebut dapat disimpulkan bahwa adalah terdapat kesalahan pemilihan dan pembentukan kata dalam hal penggunaan kata hubung intrakalimat dan antarkalimat, kata depan, unsur serapan, kata tidak baku,dan kata bentukan setelah mendapat imbuhan.

Hasil penelitian ini disarankan dapat dimanfaatkan oleh semua pihak, terutama kalangan media massa dan pihakterkaitlainnya, untuk dilakukan perbaikan.

\section{DAFTAR PUSTAKA}

Alfiyani, C. (2020). Analisis Kesalahan Berbahasa Surat Kabar Jawa Pos dan Radar Solo pada Rubrik "Trevelling" Edisi Bulan Januari-Maret tahun 2020. Ksatra: Jurnal Kajian Bahasa Dan Sastra, 2(1), 33--44.

Banjarmasin Post. (2019).

Barito Post. (2019).

Dinanti, N. F. (2019). Analisis Kesalahan

Penggunaan Bahasa Indonesia pada Jurnal Ilmiah Pendidikan MIPA FKIP
Univeristas Bengkulu. Jurnal Ilmiah Korpus, 3(2), 191--202. https://wwwjstor-

org.libproxy.boisestate.edu/stable/251 76555? Search $=$ yes\&resultItemClick $=\mathrm{t}$ rue\&search Text $=\% 28$ Choosing\&sear chText $=$ the\&searchText $=$ best\&search Text $=$ research\&searchText $=$ design\&s earchText=for\&searchText=each\&sea rchText=question.\%29\&searchText= AND

Kalimantan Post. (2019).

Keraf, G. (2002). Diksi dan Gaya Bahasa. Nusa Indah.

Mata Banua. (2019).

NFN, D. (2018). Kemapuan Menulis Naratif Guru Bahasa dan Sastra Indonesia di kabupaten Boalemo: Suatu Penelitian Awal. Jurnal Kebahasaan Dan Kesastraan Telaga Bahasa, 6(1), 405--420.

https://doi.org/https://doi.org/10.3684 3/tb.v6i1.47

Nisa, K. (2018). Analisis Kesalahan Berbahasa pada Berita dalam Media Surat Kabar Sinar Indonesia Baru. Jurnal Bindo Sastra, Volume 2, .

Radar Banjarmasin. (2019).

Sasangka, S. S. T. W. (2018). Gapura Bahasa Indonesia. Almatera.

Sobur, A. (2001). Analisis Teks: Suatu Pengantar untuk Analisis Wacana, Analisis Semiotika, dan Analisis Framing. Remaja, Bandung. Sudaryanto. (1993). Metode dan Aneka Teknik Analisis Bahasa. Duta Wacana University Press. 
Telaga Bahasa Vol.8, No.2, Oktober 2020 